НАУКОВИЙ ВІСНин

cientific messenger of Lviv National University

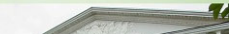

(1)

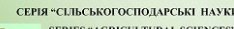

Том 22 № 93

2020
Науковий вісник Дьвівського національного університету ветеринарної медицини та біотехнологій імені С.3. Гжицького. Серія: Сільськогосподарські науки

Scientific Messenger of Lviv National University of Veterinary Medicine and Biotechnologies. Series: Agricultural sciences

https://nvlvet.com.ua/index.php/agriculture

UDC 639.31 .043

\title{
Features of rainbow trout farming technology in PE "Zakhidna Rybna Kompania", for feeding with Aguafeed Fischfutteer
}

\author{
V. I. Bozhyk, O. V. Bozhyk
}

Stepan Gzhytskyi National University of Veterinary Medicine and Biotechnologies Lviv, Ukraine

Article info

Received 17.09.2020

Received in revised form 15.10.2020

Accepted 16.10.2020

Stepan Gzhytskyi National University of Veterinary Medicine and Biotechnologies Lviv,

Pekarska Str., 50, Lviv,

79010, Ukraine.

Tel.: +38-097-585-45-14

E-mail:vbr.bozyk@gmail.com
Bozhyk, V. I., \& Bozhyk, O. V. (2020). Features of rainbow trout farming technology in PE "Zakhidna Rybna Kompania", for feeding with Aguafeed Fischfutteer. Scientific Messenger of Lviv National University of Veterinary Medicine and Biotechnologies. Series: Agricultural sciences, 22(93), 142-147. doi: 10.32718/nvlvet-a9324

The production of trout products in ponds and aquaculture farms is based on modern and long-term plans for technology and intensification of production, through the introduction of the latest approaches, by borrowing the experience of leading foreign producers, expanding production areas and sectoral investments. The main indicator that characterizes the efficiency of fisheries and reflects the state of production and the level of its economic indicators. is fish productivity Growing trout in aquaculture in a closed water supply is associated with high planting densities per unit area, the use of high-protein granular feed, which must fully meet the needs of fish in all necessary nutrients to ensure a balanced diet. In modern farms for feeding trout use high-protein feed mixtures in the form of grits and pellets. The dynamics of the intensity of growth and development of rainbow trout mainly depends on the location of the farm, the quality of the water supply source, the feeding regime of fish and the quality of feed. Therefore, the aim of the work was based on a review of literature sources and analysis of economic activity of the studied farm to give a general description of trout feed, Aquafeed Fischfutter, used for fish feeding, and determine their effectiveness, taking into account geographical location and abiotic and biotic factors. In addition, the study fish performance when feeding these feeds. Conduct research on the growth rate of rainbow trout, changes in weight and length of larvae, fry, yearlings and commercial fish, in tray, pool and pond cultivation. Develop a scheme for growing all age groups of trout on these feeds. Establish indicators of quality, nutritional value, feed ratio of starting, growth and production feeds. To give an objective assessment of their impact on the growth of larvae, fry, yearlings and commercial rainbow trout in the conditions of trout farming PE "Zakhidna Rybna Kompania", Perimyshlyany district, Lviv region. The conducted research gives the basis to claim that this compound feed guarantees high daily gain. Being a high-energy feed, its use does not lead to obesity of fish. With intensive feeding, a good ratio of price and productivity of farmed fish is realized. The risk of contamination of water bodies and fish is very low, due to the low phosphorus content and good digestibility of feed - $1.1 \mathrm{~kg}$ of feed $/ \mathrm{kg}$ of fish growth. The feed corresponds to the best world indicators in accordance with buoyancy and stability in water.

Key words: rainbow trout, cultivation technology, Aguafeed Fischfutteer compound feeds, aquaculture industry, ration, feeding norms, growth intensity, feed coefficient, fish productivity, nutritional value of feed, economic efficiency of feed.

\section{Особливості технології вирощування райдужної форелі у ПП Західна рибна компанія, за годівлі комбікормами Aguafeed Fischfutteer}

\author{
В. Й. Божик, О. В. Божик
}

Львівський національний університет ветеринарної медицини та біотехнологій імені С. 3. Гжицького, м. Львів, Украӥна 
Виробництво продукиї форелівництва у ставових та аквакультурних господарствах трунтується на сучасному та перспективному планах, щуодо технології і інтенсифікації виробництва, завдяки впровадженню найновіших підходів, шляхом запозичення досвіду передових іноземних виробників, розииренню виробничих площ, а також галузевим інвестиціям. Основний показник, який характеризує ефективність роботи рибного господарства та відображає стан виробництва і рівень його економічних показників. є рибопродуктивність Вирощування форелі в умовах аквакультури за умови замкнутого водопостачання пов'язано з високими щільностями посадки на одинищю площі, використанні високобілкових гранульованих комбікормів, які повинні повністю задовольняти потреби риб у всіх необхідних поживних речовинах, чим забезпечити збалансоване живлення. У сучасних господарствах для годівлі форелі застосовують високобілкові кормові суміші у вигляді крупки та гранули. Динаміка інтенсивності росту і розвитку райдужної форелі в основному залежить від умов розташування господарства, якості джерела водопостачання, режиму годівлі риб та якісного складу комбікормів. Через те, метою роботи було на підставі огляду літературних джерел і аналізу господарської діяльності досліджуваного господарства дати загальну характеристику кормів для форелі, підприємства Aqиаfееd Fischfuttеr, які використовуюся для годівлі риби, та визначити їх ефективність, з урахуванням географічного розташування та абіотичних $і$ біотичних факторів кліматичної зони. Також вивчити рибоводні показники при годівлі циими комбікормами.. Провести дослідження щзодо темпу росту райдужної форелі, зміні маси і довжини личинок, мальків, иьоголіток і товарної риби, при лотковому, басейновому та ставовому вирощуванні. Розробити схему вирощування всіх вікових груп форелі на циих кормах. Встановити показники якості, поживності, кормового коефіцієнту стартових, ростових та продукційних комбікормів. Дати об'єктивну оцінку їх впливу на ріст личинок, мальків, цьоголіток і товарної райдужної форелі в умовах форелевого господарства ПП “Західна рибна компанія”, Перимишлянського району, Львівської області. Проведені дослідження дають підставу стверджувати, ичо даний комбікорм гарантує високий добовий приріст. Являючись високоенергетичним кормом, його застосування не приводить до ожиріння риби. При інтенсивній годівлі реалізується хороше співвідношення ціни та продуктивності вирощуваної риби. Ризик забрудненості водойм та риби дуже низький, завдяки незначному вмісту фосфору та хорошій засвоєності корму, Кормовий коефіцієнт стартового комбікорму для личинок, мальків і цьоголіток становить 0,7-0,8, а продукційний для однорічок та дволіток (товарна форель) - 1,0-1,1 кг корму/кг приросту риби. Корм відповідно до плавучості і стабільності у воді відповідає найкращим світовим показникам.

Ключові слова: райдужна форель, технологія вирощування, комбікорми Aguаfeеd Fischfutteеr, галузь аквакультура, раціон, норми годівлі, інтенсивність росту, кормовий коефіцієнт, рибопродуктивність, поживна иінність корму, економічна ефективність кормів.

\section{Вступ}

На сучасному етапі розвитку рибництва та аквакультури, одним із найбільш важливих завдань галузі, $є$ підвищення ऑї продуктивності за рахунок постійного вдосконалення рівня, різного роду інтенсифікаційних заходів. Більш сучасні його форми, передбачають розширення та впровадження нових об'єктів вирощування, потребують також якісного покращання роботи рибоводної та іхтіопатологічної служб, правильно організованої годівля риби високоякісними, повноцінними за поживністю комбікормами. Форель яку вирощують у високотехнологічних господарствах годують гранульованими комбікормами, до складу яких включають рибне та крилеве борошно, сухі відходи м'ясо-молочного виробництва, шроти та жмихи масляничних культур, сухі продукти мікробіологічного синтезу, зерно та його відходи, жири тваринного та рослинного походження. Комбікорми повинні бути збалансовані за незамінними амінокислотами, жиром 3 достатньою кількістю ненасичених жирних кислот, а також містити вітаміни, мікро і макроелементи у відповідному співвідношені до вікових груп форелі. (Zheltov, 2003; Bozhyk et al., 2004; Hrytsyniak, 2007; Yehorov \& Fihurska, 2010).

Згідно специфікації комбікормові підприємства на сьогодні виробляють стартові та продукційні комбікорми для вирощування лососевих риб в умовах ставових господарств та аквакультури. Стартові комбікорми виробляються у вигляді крупки, з поліпшеним якісним складом і більш високим вмістом обмінної енергії та вітамінів, продукційні, високобілкові у вигляді еліпсоїдних гранул. Розмір крупки та гранул повинен відповідати розміру вирощуваної риби. Стартові корми використовують тільки для вирощування молоді масою до 5-6 г, а далі - задають продукційні корми до досягнення фореллю товарної маси. Годів- лю проводять за визначеними нормами, які відповідають рівню оптимальних потреб риби, з урахуванням рибоводно-економічної ефективності господарювання.

В процесі вирощування форелі необхідно орієнтуватись на точні розрахунки необхідної норми корму 3 урахуванням розміру та віку риби, температури води, вмісту кисню, $\mathrm{pH}$ - води, калорійності корму. Для визначення добових норм годівлі використовують таблиці нормованої годівлі риби. Кормовий коефіцієнт гранульованого комбікорму з вмістом протеїну 40-60 \%, при обмінній енергії 2500-3000 ккал/кг для личинок, мальків та цьогорічок становить $0,7-0,8$, для однорічок та дволіток (товарна риба) -1,0-1,2.

Meта $i$ завдання роботи полягали у дослідженні темпу росту райдужної форелі, зміні маси і довжини личинок, мальків, цьоголіток і товарної риби, при лотковому, басейновому та ставовому вирощуванні. Вивчити рибоводні показники при годівлі комбікормами Aguafeed Fischfutteer. Розробити схему вирощування всіх вікових груп форелі на цих кормах. Встановити показники якості, поживності, кормового коефіцієнту стартових, ростових та продукційних комбікормів фірми Aguafeed Fischfutteer, Дати об'єктивну оцінку їх впливу на ріст личинок, мальків, цьоголіток і товарної райдужної форелі в умовах форелевого господарства ПП “Західна рибна компанія”, Перимишлянського району, Львівської області.

\section{Матеріал і методика досліджень}

В якості матеріалу для роботи були використані дані комплексних досліджень, проведених за період 2018-2020 років, в форелевому господарстві ПП “Західна рибна компанія”, Перемишлянського району, Львівської області. Протягом періоду вирощування, простежено технологію відтворення і вирощування 
райдужної форелі з годівлею комбікормами, Aguafeed Fischfutteer за розмірними та поживними показниками 3 урахуванням режимів вирощування до вікових груп. Першочергова увага приділена температурному, кисневому режимам, $\mathrm{pH}$ середовища, відповідно до умов і щільності вирощування кожної вікової групи. Температура води за весняно-літній період коливалась від 8-10 до $16^{\circ} \mathrm{C}$, а осінньо-зимовий $4-10{ }^{\circ} \mathrm{C}$. Кисневий режим витримувався на рівні $6,5-10$ мг/л, $\mathrm{O}^{2}, \mathrm{pH}$ середовища $6,8-7,6$.

Вільні ембріони і личинки утримувались в лотках інкубаційних апаратів Шустера, з подальшою пересадкою у підрощувальні ємності. Мальки і цьоголітки вирощувались у лотках і басейнах робочим об'ємом 1-5 м 3 , 3 джерельним, частково зворотним водообміном до 15 хв. Цьоголітки, цьогорічки і товарна форель вирощувалась у бетонних басейнах, площею 36 $120 \mathrm{~m}^{3}$, 3 водообмінок протягом 2 год.

Щільність витримування вільних ембріонів скла-

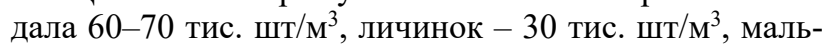
ків до маси 1 г - 2,5-3 тис. шт/ $\mathrm{M}^{3}$, цьоголіток $1-1,2-$ 2,0 тис. шт/ $\mathbf{M}^{3}$, однорічок, дволіток і товарну форель від 600 до 200-250 шт/ $\mathrm{M}^{3}$.

В процесі вирощування форелі проводили іiі сортування за вагою та розмірами, а також контрольне зважування. Для вивчення особливостей росту рівня зміни маси і довжини, кожні 10 днів проводили зважування і проміри риби. Визначали також рибоводні показники, як виживання, приріст іхтіомаси і затрати корму.

Годівлю риби проводили згідно вікових груп та таблиць фірми Aguafeed Fischfutteer. В процесі дослідів постійно контролювали хідрохімічний режим лотків, басейнів та ставів.
Основні рибогосподарські дослідження були проведені за загальноприйнятими у рибництві методиками (Egorov et al., 2011; Pivtorak \& Bobel, 2017).

\section{Результати та їх обговорення}

Аналіз технології вирощування райдужної форелі, розпочато 3 вивчення місцевості, фізикогеографічного розташування господарства, джерела його живлення, 3 урахуванням впливу абіотичних i біотичних факторів місцевості, інтенсифікаційних заходів.

Клімат басейну розташування господарства помірно-континентальний, 3 відносно м'якою зимою i вологим, помірно теплим літом. Максимальна і мінімальна температури повітря відповідно рівні $+35{ }^{\circ} \mathrm{C}$ i $-32{ }^{\circ} \mathrm{C}$. Сніговий покрив в басейні розташування господарства спостерігається у 84 \% зими. Середня висота снігового покриву від 26 до 48 см 3 промерзанням грунту до 83 см. Кількість опадів на рік становить 765 мм. Водоприймачем гранично - допустимих скидів є басейн ріки Свірж, розташований в межах Подільської височини.

Живлення інкубаторію, підрощувальної та вирощувальної системи лотків і ставів рибгосподарства здійснюється 3 підземних джерел самопливом, та за допомогою насосів і тільки в окремих випадках задіюється ріка Свірж, яка має переважно джерельне водонаповнення, за винятком весняних паводкових та осінніх дощових стоків.

Сприятлива температура води в межах $8-12^{\circ} \mathrm{C}$, дає можливість продуктивно використовувати всі місяці року, при яких форель повноцінно споживає комбікорми та інтенсивно росте.

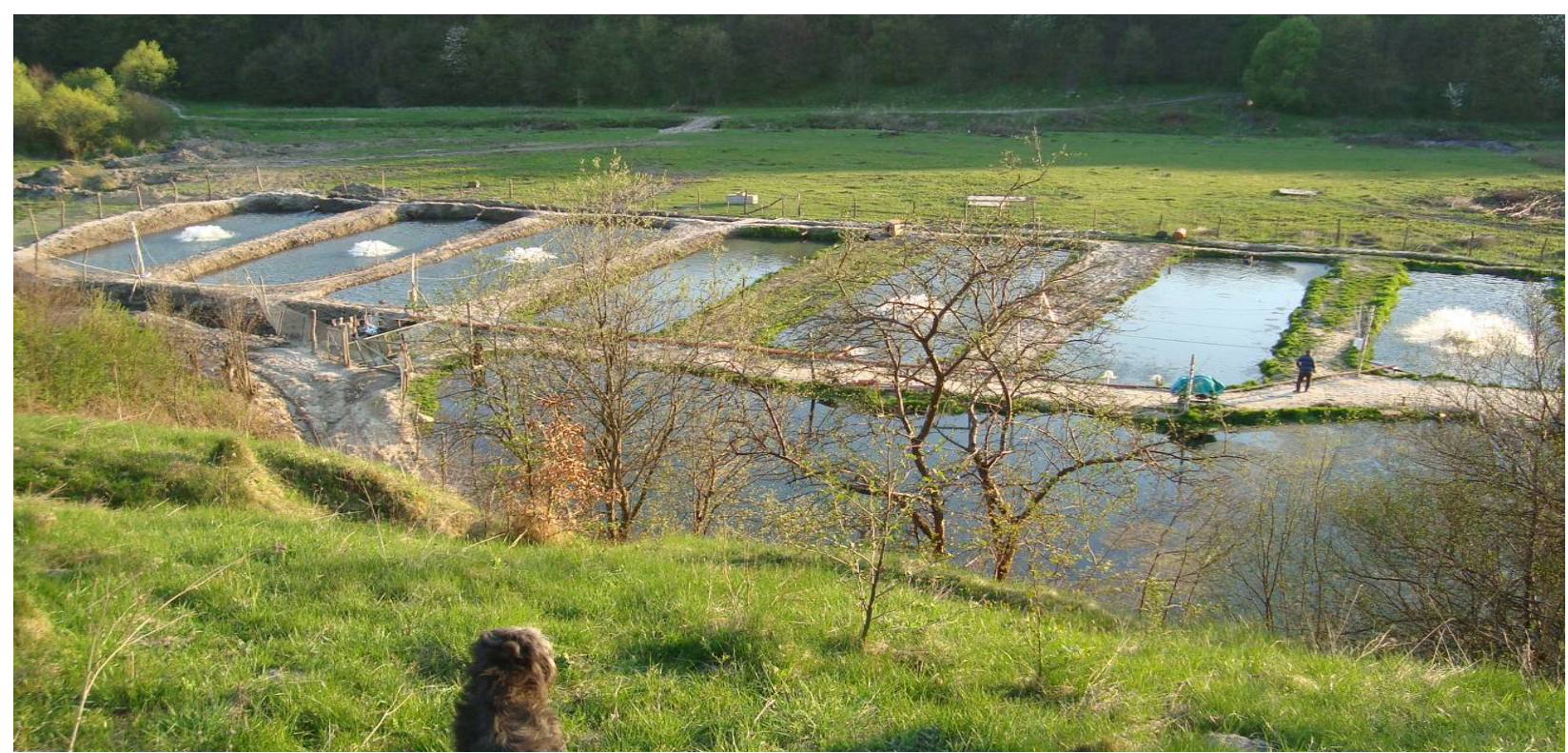

Рис. 1. Стави для вирощування форелі

В господарстві наявне маточне стадо, в склад якого входить райдужна форель, камлоопс, форель Адлер-золотиста, стальноголовий лосось та голець, чотирьох - шести та семи-восьми річного віку, середньою вагою 1,5 - 6,0 кг.
Комбікорми які згодовувались у господарстві, виробляє спеціалізоване підприємство, в першу чергу зорієнтовані на їх якість, екологічність, охорону навколишнього середовища, 3 урахуванням здоров'я, фізіологічного стану, властивості риби переносити 
навантаження, якість харчової риби, а також рентабельність виробництва. Рибний комбікорм збалансований за вмістом поживних речовин, засвоєністю, енергетичною цінністю та розподілом в організмі риб. Вміст поживних речовин і їх засвоєність залежить від вмісту протеїну, жиру і вуглеводів (БАР), що встановлено в виробничих умовах. Показники сирої клітковини так як і золи, які знижують енергетичну цінність комбікорму знаходяться у незначних кількостях та наявністі фосфору із-за його негативної дії на оточуюче середовище.

В процесі вирощування риби у водоймах за умов інтенсифікації, особливо актуальними $є$ вимоги до навколишнього середовища, важливе значення має фактор попадання поживних речовин через комбікорми в водойми. Можливі ризики забруднення оточуючого середовища залежать від кормового коефіцієнту і вмісту у кормі та рибі фосфору і азоту.

В процесі вирощування форелі необхідно орієнтуватись на точні розрахунки необхідної норми корму 3 урахуванням розміру та віку риби, температури води, вмісту кисню, $\mathrm{pH}$ - води, калорійності корму. Для визначення добових норм годівлі використовують таблиці нормованої годівлі риби. Кормовий коефіцієнт гранульованого комбікорму з вмістом протеїну 40 - 60 \%, обмінній енергії 2500-3000 ккал/кг для личинок, мальків та цьогорічок становить 0,7-0,8, для однорічок та дволіток (товарна риба) - 1,0-1,2 .

Для вирощування мальків і молоді форелі підприємство виготовляє стартові, а для старших вікових груп продукційні комбікорми. Крім того виробляються спеціальні комбікорми для годівлі плідників риб.

До складу комбікормів входять низькотемпературне рибне борошно, гідротермічно оброблена пшениця, тритікали, рибячий жир, ріпаковий шрот, білок гороховий, екстракт високопротеїнової сої, м'ясокісткове борошно з відходів і пір'я птиці, порошок гемоглобіну, дріжджі, премікс з вітамінів (А, Д, Е), мінералів, мікроелементів (залізо, мідь, сульфат/пентагідрат, цинк, марганець, кобальт, йод, селен та ін., ліцетин. Антиоксидант: бутилгідроситолуол. Дані комбікорми забезпечують організм необхідною кількістю поживних речовин, окремих вітамінів та мінеральних речовин, що сприяє нормальній життєдіяльності вирощуваних риб, збереженню молоді, збільшенню продуктивності і природного забарвлення риб.

Годівля здійснюється згідно таблиць з урахуванням ваги риби, розмірів гранул, та процентної дачі комбікорму відповідно до температури води і маси риби.

Дослідженнями встановлено, що після викльову, за температури води не вище $10-11{ }^{\circ} \mathrm{C}$, вільні ембріони витримували у лотоках інкубаційних апаратів Шустера, а далі висаджували у прямокутні скловолоконні лотки. Щільність посадки вільних ембріонів складала

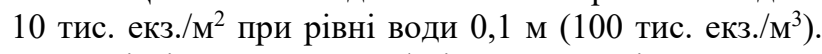
При вмісті кисню 7-9 мг/л і температурі води $10^{\circ} \mathrm{C}$ витрати води складати 0,7-0,9 л/хв на 1 тис. ембріонів або 4,9-6,5 л/хв на 1 кг (за маси ембріонів 0,08-0,2 г, в середньому 0,14 г). Таким чином, повний водообмін здійснювався за 12-15 хв. Через 5-7 діб у ембріонів появився негативний фототаксис та (роїння), тому лотки закривали кришками і влаштовували рівномірний потік води.

При настанні личинкового періоду розвитку та розсмоктуванню жовткового міхурця на 50\%, підйому молоді форелі на плав, починали годівлю стартовими комбікормами FB 55/15 ЕX, протягом світлового дня, через кожну годину, за температури води $11-12^{\circ} \mathrm{C}$, при вмісті кисню 7-9 мг/л.

Щільність посадки залишається тією ж, але рівень води підвищується до 0,2 м, тому щільність знижується до 50 тис. екз./м². Витрати води зростають до 1,2-1,9 л/хв на 1 тис. личинок (або 4,9-7,7 л/хв на 1 кг при масі личинок 0,15-0,35 г. Повний водообмін здійснюється за 10-15 хв.

При розсмоктуванні жовткового мішка на 1/2-2/3 личинки періодично підіймались у товщу води, а при залишку 25 \% його початкової величини - починають плавати, не опускаючись на дно. В процесі вирощування личинок слідкували за чистотою басейнів, температурним і газовим режимами води, проводили їх регулярну годівлю.

Після завершення розсмоктування жовткового мішка і повного переходу молоді форелі на зовнішній корм, настає мальковий період іiі розвитку і росту. Для вирощування мальків ми використовували прямокутні лотки 4,5 х 0,5 х 0,6 м та шестикутні басейни 2,5 х 2,5 х 0,8 м із центральним стоком та круговим потоком води.

При вирощуванні мальків важливим фактором успіху є дотримання оптимальних умов гідрологічного режиму і в першу чергу інтенсивності водообміну. Температура води в цей період складала $12-16{ }^{\circ} \mathrm{C}$, вміст кисню - на рівні 8 - 10 мг/л. Щільність посадки залежав від маси: до маси 1 г - 10 тис. екз $/ \mathrm{M}^{2}$ при рівні, води до 0,4 м (у перерахунку це складає 25 тис. екз./ $\left.\mathrm{M}^{3}\right)$. Витрати води підвищили 3-5 л/хв на 1 тис. екз. мальків, або від 5-8 л/хв на початку до 3-5 л/хв у кінці періоду на 1 кг мальків при зміні води кожні 1015 хв.

При вирощуванні молоді масою від 1 до 3-4 г щільність посадки знижувадась до 3 тис. екз./ $\mathrm{M}^{2}$ при рівні води 0,4 м (7,5 тис. екз./ $\left.\mathrm{M}^{3}\right)$, за витрати води $8-$ 13 л/хв на 1 тис. екз., з подальшим зниженням до 2,53,5 л/хв на 1 кг риби і заміні при заміні кожні 1015 хв. У процесі вирощування мальків, їх годівлю проводили кормами FB 52/20 ЕX. Одночасно слідкують за чистотою басейнів, температурним і гідрохімічним режимом.

Для вирощування цьоголіток, використовують стави і басейни. Найбільш доцільно застосовувати інтенсивне вирощування їх у бетонних ставах або басейнах. Залежно від водного режиму щільність посадки форелі масою 1 г у басейнах становить від 2 до 4 тис. екз./ $\mathrm{M}^{3}$ за витрат води 35-50 л/хв на 1 тис. екз. риби.

При вирощуванні цьогорічок в умовах господарства ПП “Західна рибна компанія", використовують бетонні стави, та пластикові басейни.

У процесі вирощування цьогорічки форелі виявляли різний темп росту, який продовжувався 130-140 діб із сортуванням за лінійними розмірами та масою 
тіла 3 рази. Також проводили профілактичні обробки у розчинах формаліну та хлораміну, які вносили на притоку води. В процесі вирощування, слідкували за загальним станом мальків, їх темпом росту та активністю щодо поїдання комбікормів. По завершенні періоду вирощування мальки (цьогорічки) досягнули середньої маси 23-25 г за виживання - близько $90 \%$. Годівлю їх здійснювали протягом світлової доби до 5-4 рази комбікормами FM 49/22 EX до 15 г, а далі FM 50/16 ЕХ до маси 25-30 г.

Товарне вирощування форелі у господарстві “Західна рибна компанія”, здійснюється у земляних ставах та бетонних басейнах, після старанної їх очистки та дезінфекції негашеним вапном та побілкою стінок басейнів вапняним молочком. Надалі їх промивають та заповнюють водою. Водойми які використовуються під вирощування товарної форелі мають прямокутну форму, відношення сторін 1:5 та 1:6, за площі від 100 до $320 \mathrm{~m}^{2}$, об'ємом води 100-400 м², при глубині ставів 1-1,2 м.

Щільність посадки молоді форелі у басейни становить 100-150 екз./м³ , заміна води в них здійснюється на протязі 15-25 хв. За таких умов продукція у басейнах досягає 30-50 кг/м². У садках за температури води вище $14{ }^{\circ} \mathrm{C}$ і концентрації розчиненого у воді кисню не нище 7 мг/л використовують щільність посадки форелі від 150 до 250 екз./ $\mathrm{M}^{3}$. У ставах щільність посадки зменшують до 30-50 екз./ $\mathrm{M}^{3}$. Розхід води в таких ставах повинен бути в межах 600 л/год, або 6 л/хв на 1 кг риби. Згідно середніх нормативних показників розхід води повинен бути не нижче 350-400 л/год, на 1 кг ж. маси риби.

У період вирощування рибу регулярно годують, ретельно чистять ємкості (особливо лотки), від залишків їжі. Щоденно вимірюють температуру води, яка не повинна перевищувати $16-18^{\circ} \mathrm{C}$. Вміст розчиненого у воді кисню контролюється також щодня, концентрація його має бути не нижчою 7 мг/л.

У процесі вирощування товарної форелі не менше двох разів на сезон сортують рибу за масою на дві розмірні групи, стежать постійно за санітарногігієнічним станом ємкостей та станом здоров'я риби. За умови дотримання всіх технологічних вимог за 120-150 діб вирощування маса дволіток досягає 300350 г. Відхід риби впродовж періоду вирощування не перевищував $10 \%$.

Годівлю форелі на товарне вирощування здійснювали у ставах, та в басейнах продукційними комбікормами FM 44/26 ЕX до маси 200 г, а далі FM 44/24 EX до маси 350-500 г. При годівлі стежили за дозуванням і раціональними витратами кормів. Корми задавати в одному і тому ж місці басейну, або ставу і в один той же час доби. При згодовуванні вручну добову даванку корму ділили відповідно кратності годівлі, роблячи поправку на температуру води. Найбільш інтенсивно форель споживала корми за температури $14-16{ }^{\circ} \mathrm{C}$. Добові норми годівлі різнорозмірної та різновікової форелі здійснювали згідно нормованих таблиць, враховуючи температуру та їх масу.

Для вирощування мальків і молоді форелі використовували стартові комбікорми таких типів: FB 55/15
EX i FB 52/20 EX, а для цьоголіток FM 49/22 EX I рідше FM 50/16 ЕX.

Дещо ширшу гаму за поживністю використовували продукційних кормів, при годівлі мальків та старших вікових груп форелі. Такі корми як FM 44/26 EX, FM 44/24 EX згодовували малькам форелі, надалі при досягненні 100 г, використовували комбікорми FM 44/20 ЕX, на завершальних етапах годівлі застосовували комбікорм FM 44/18 EX, в окремих випадках FM 42/12 EX.

Дані комбікорми зорієнтовані на їх якість, екологічність, охорону навколишнього середовища, з урахуванням здоров'я, фізіологічного стану, властивості риби переносити навантаження, якість харчової риби, а також рентабельність виробництва.

Годівля цими комбікормами гарантує високий добовий приріст. Являючись високоенергетичним кормом, його застосування не приводить до ожиріння риби. При інтенсивній годівлі реалізується хороше співвідношення ціни та продуктивності вирощуваної риби. Ризик забрудненості водойм та риби дуже низький, завдяки незначному вмісту фосфору та хорошій засвоєності корму, середній кормовий коефіцієнт склав від 0,8 до 1,0 кг корму/кг приросту риби. Корм відповідно до плавучості і стабільності у воді відповідає найкращим світовим показникам.

\section{Висновки}

Високоякісний спеціалізований комбікорм “Aguafeed Fischfutteer", який виробляється на підприємстві Спеціальфуттерміттельверк Беесков ГмбХ, зорієнтований на його якість, екологічність, охорону навколишнього середовища, з урахуванням здоров'я, фізіологічного стану, властивості риби переносити навантаження, якість харчової риби, а також спрямований на рентабельність виробництва у рибництві та аквакультурі.

Проведені дослідження дають підставу стверджувати, що даний комбікорм гарантує високий добовий приріст. Являючись високоенергетичним кормом, його застосування не приводить до ожиріння риби. При інтенсивній годівлі реалізується хороше співвідношення ціни та продуктивності вирощуваної риби. Ризик забрудненості водойм та риби дуже низький, завдяки незначному вмісту фосфору та хорошій засвоєності корму, Кормовий коефіцієнт стартового комбікорму для личинок, мальків і цьоголіток становить 0,7-0,8, а продукційний для однорічок та дволіток (товарна форель) - 1,0-1,1 кг корму/кг приросту риби. Корм відповідно до плавучості і стабільності у воді відповідає найкращим світовим показникам.

\section{References}

Bozhyk, V., Bulatovych, M., Hrekh, V., \& Tsymbala, H. (2004). Intensyvne vyroshchuvannia posadkovoho materialu raiduzhnoi foreli $\mathrm{v}$ rybohospodarstvakh Ukrainskykh Karpat. Silskyi hospodar, 3-4, 31-35 (in Ukrainian).

Egorov, B. V., Chajka, I. K., Brazhenko, V. E., \&Voeckaja, E. E. (2011). Metodicheskie ukazanija k 
vypolneniju laboratornyh rabot po kursu "Tehnologija kombikormovogo proizvodstva". Odessa: ONAPT (in Russian).

Hrytsyniak, I. I. (2007). Naukovo-praktychni osnovy ratsionalnoi hodivli ryb. K.: Rybka moia (in Ukrainian).

Pivtorak, Ya. I., \& Bobel, I. Yu. (2017). Intensyvnist rostu i rozvytku raiduzhnoi foreli za vykorystannia kormiv Aller Aqua ta Aquafeed Fischfutter. Naukovyi visnyk Lvivskoho natsionalnoho universytetu veterynarnoi medytsyny ta biotekhnolohii imeni S. Z. Gzhytskoho. Seriia: Silskohospodarski nauky, 19(79), 73-77. doi: 10.15421/nvlvet79 (in Ukrainian).
Sherman, I. M., Hrynzhevskyi, M. A., \& Zheltov, Yu. O. (2002). Naukove obgruntuvannia ratsionalnoi hodivli ryb. K.: Vyshcha osvita (in Ukrainian).

Yehorov, B. V., \& Fihurska, L. V. (2010). Porivnialnyi analiz prohram hodivli foreli. Zernovi produkty i kombikormy. 2, 46-50. URL: http://nbuv.gov.ua/UJRN/ Zpik_2010_2_18 (in Ukrainian).

Zheltov, Yu. A. (2003). Metodychni vkazivky Z provedennia doslidiv po hodivli ryb. Rybne hospodarstvo, 62, 23-28. doi: 10.15407/fsu (in Ukrainian). 